\title{
SCAPHOSEPALUM TARANTULA (ORCHIDACEAE: PLEUROTHALLIDINAE), A NEW SPECIES FROM ECUADOR
}

\author{
Luis E. Baquero ${ }^{1,2,3}$, Alexander Hirtz $^{2}$ \& Gabriel Iturralde ${ }^{1,2}$ \\ ${ }^{1}$ Carrera de Ingeniería Agroindustrial y Alimentos. Facultad de Ingeniería y Ciencias \\ Agropecuarias. Universidad de Las Américas, Calle José Queri, Quito 170137, Pichincha, Ecuador \\ ${ }^{2}$ Jardín Botánico de Quito, Pichincha, Ecuador \\ ${ }^{3}$ Author for correspondence: 1baquero@hotmail.com
}

\begin{abstract}
AвSTRACt. A new species, Scaphosepalum tarantula, is described. It is recognized by the medium-sized plants with grey-green leaves suffused with red-brown to purple stains at the petioles; densely fimbriated, red-brown to sanguine flowers, spiky tails of the lateral sepals and a dark sanguine, wingless lip. It is here compared to Scaphosepalum fimbriatum with which it shares similarities.

Resumen. Se describe aquí Scaphosepalum tarantula, una nueva especie. Se reconoce por las plantas de tamaño mediano con hojas verde-gris salpicadas por manchas rojo-café en los peciolos; las flores densamente fimbriadas, café-rojizo a color sangre, con las caudas de los sépalos laterales con púas y el labelo sin alas. Se lo compara con Scaphosepalum fimbriatum, con el que comparte rasgos similares.
\end{abstract}

Key words: new species, Pichincha, Scaphosepalum fimbriatum, sympatric species

Introduction. There are more than 50 species of Scaphosepalum Pfitzer (Luer 1988, 1991, 1992, 1993, 1998a, 1998b, 2000, 2009, Pridgeon et al. 2001, Endara et al. 2011, Chase et al. 2015, Valenzuela Gamarra 2015, Karremans 2016, Karremans et al.2016, Baquero 2017). Scaphosepalum species are recognized from other members in the Pleurothallidinae mainly by the osmophores at the apex of the lateral sepals, sepaline tails of variable length, and the non-resupinate flowers (Luer 1988, Pridgeon et al. 2001, Endara et al. 2011, Karremans et al. 2016). The known species with long, fimbriate, spiculate, sepaline tails are Scaphosepalum fimbriatum Luer \& Hirtz, S. zieglerae Baquero and $S$. beluosum Luer (Luer 1988, Baquero 2017). A species that shares these characteristics but is much smaller in size compared with $S$. zieglerae and $S$. beluosum, and differs from $S$. fimbriatum in lip morphology, was discovered close to Quito and is described here.

\section{TAXONOMIC TREATMENT}

Scaphosepalum tarantula Baquero \& Hirtz, sp. nov. (Fig. 1-3).

TYPE: Ecuador. Pichincha: Las Tolas, $0^{\circ} 04^{\prime} 14.1$ 'N 78¹3'46.3”'W, October 28, 2016, 1884 m. Luis Baquero 3092 (holotype, QCNE).
Diagnosis: Species similar to Scaphosepalum fimbriatum, from which it differs by triangular osmophores of the lateral sepals instead of quadrilateral osmophores; the pandurate, dark sanguine lip, with a rhomboid epichile instead of an elliptical-subpandurate, threelobed, purple lip; and the rhomboid petals versus the subquadrate, oblique petals of S. fimbriatum (Fig. 3).

Plant epiphytic, densely caespitose, $15-20 \mathrm{~cm}$ tall. Roots slender. Ramicauls erect, slender, 1.5$2.0 \mathrm{~cm}$ long, enclosed by $2-3$ sheaths. Leaf erect, green suffused with red-brown to purple stains at the petioles, thinly coriaceous, conduplicate, longpetiolate, $8-12 \mathrm{~cm}$ long including the petiole 1.8-3.0 $\mathrm{cm}$ long, leaf apex acute, the blade narrowly elliptical $1.0-1.5 \mathrm{~cm}$ wide, attenuate below into a slender, channeled petiole. Inflorescence a loose, distichous, successively several flowered raceme, $5-10 \mathrm{~cm}$ long, each flower borne by a slender, glabrous to faintly verrucose, descending peduncule 4-7 cm long, originating from low to medially on the ramicaul; floral bracts thin, acuminate, conduplicate, $2 \mathrm{~mm}$ long; pedicel slightly recurved, 3-5 mm long; ovary ribbed, $2 \mathrm{~mm}$ long. Sepals cream colored, densely spotted with dark-purple dots, the margins ciliate, with spiculate carinae. Dorsal sepal tricarinate, 

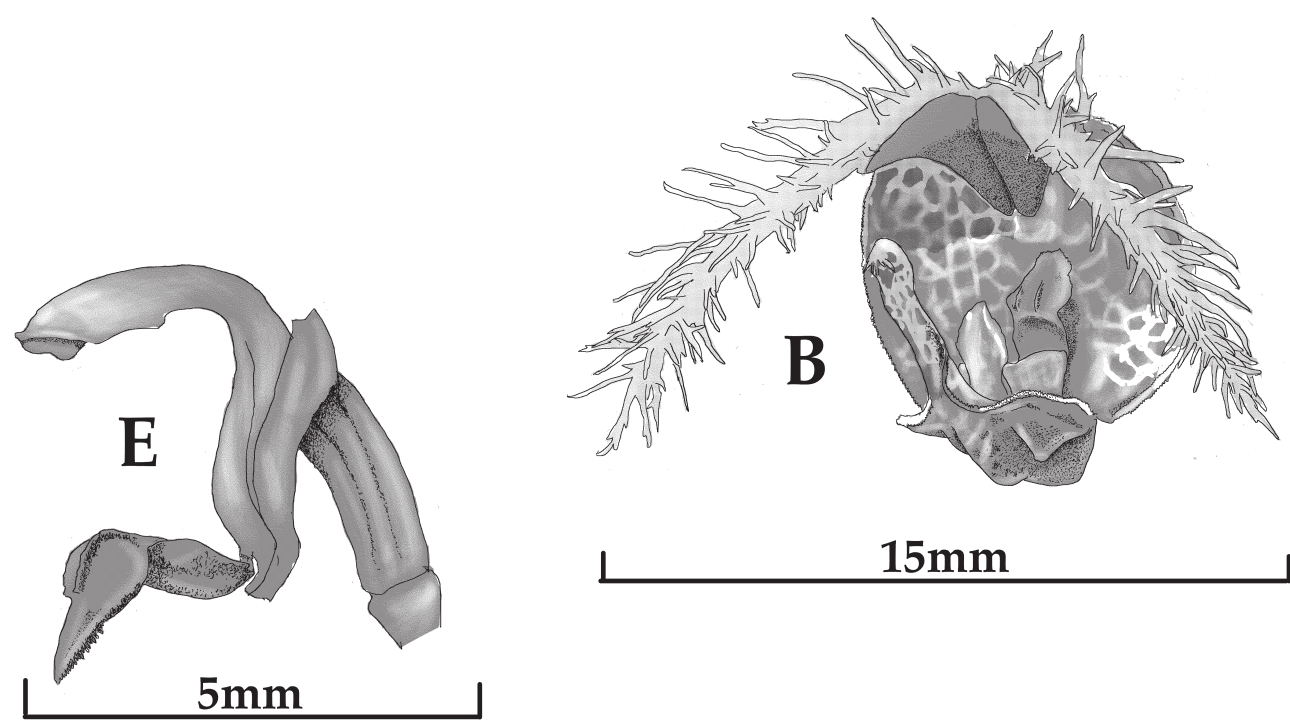

\section{$15 \mathrm{~mm}$}

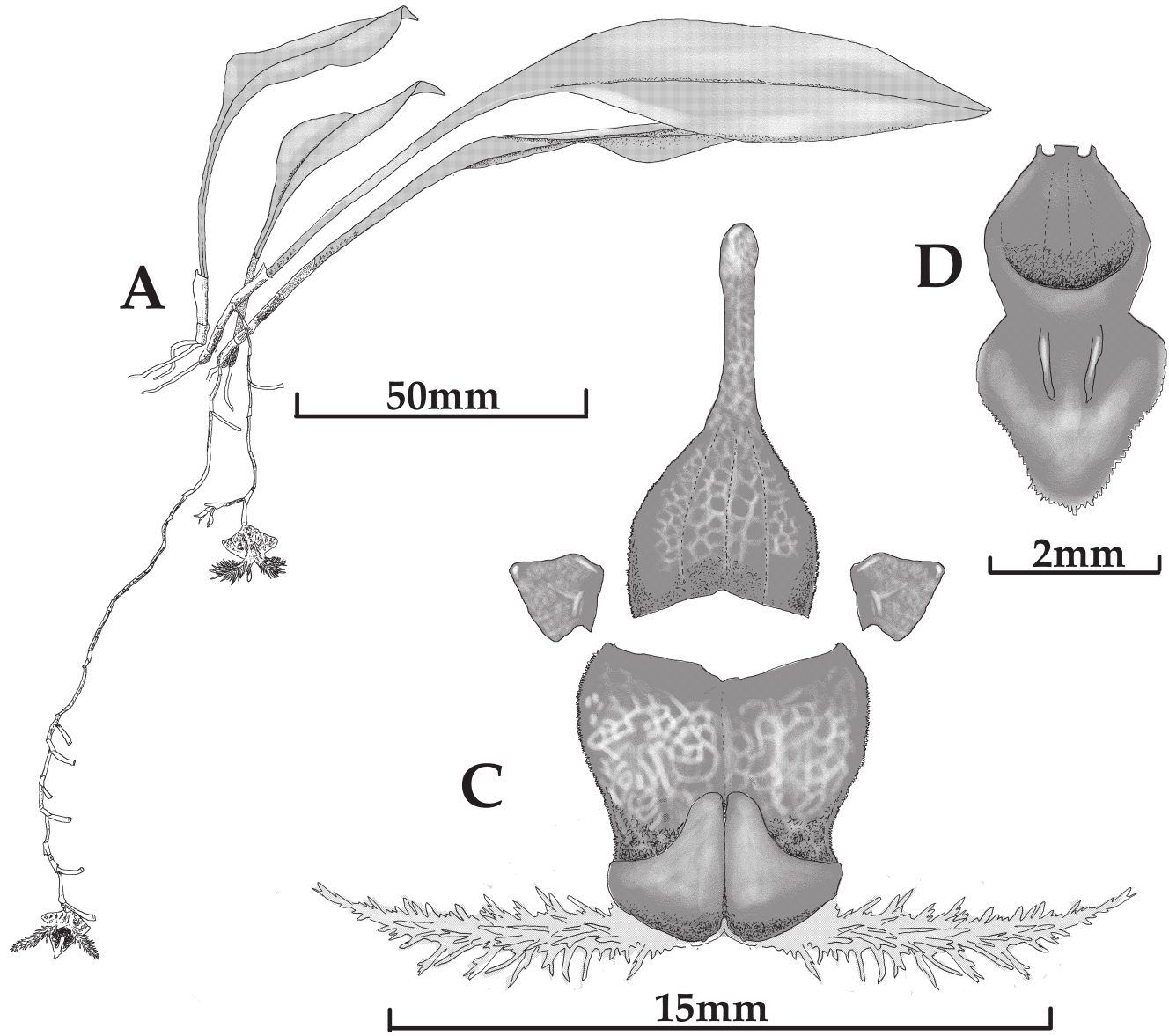

Figure 1. Scaphosepalum tarantula. A. Habit. B. Flower. C. Dissected perianth. D. Lip extended. E. Lip and column. Drawn by L. E. Baquero from the holotype. 
not spiculated, ovate and concave, $7.5 \times 4.0 \mathrm{~mm}$ unexpanded, concave below the middle and narrowly linear above the middle with revolute margins and a swollen apex. Lateral sepals connate $7 \mathrm{~mm}$ into a bifid, oblong, concave lamina $3.4 \times 7.0 \mathrm{~mm}$ unexpanded, the apical portion of each lateral sepal occupied by a thick, triangular, diverging, glabrous cushion $3.0 \times 2.5 \mathrm{~mm}$, continuous with the acute, oblique, diverging apex terminating in a decurved, yellowish-green, densely fimbriate tail, each lateral sepal $14 \mathrm{~mm}$ long including the tail. Petals orange suffused with red, solid red at the base, spotted with red towards the apex, rhomboid, acute, $2 \times 2 \mathrm{~mm}$, provided with a longitudinal callus medially, the labellar margins obtusely angled. Lip dark bloodred, pandurate, reflexed near the middle, $3.0 \times 2.1$ $\mathrm{mm}$ wide, the epichile rhomboid, fringed at the edge, the disc with a pair of tall, erect lamellae above the middle; the hypochile rectangular, slightly concave, the base truncate, minutely bilobulate. Column darkpurple at the base, fading whitish towards the apex, semi terete, slender, $2.7 \mathrm{~mm}$ long, slightly winged above the middle, with a thick foot $2.6 \mathrm{~mm}$ long. Pollinia 2, yellow. Fruits and seeds not observed.

Eponymy: Named for the large, hairy spiders of which this orchid flower is reminiscent because of the spiky tails of the sepals and dark color.

DistRIBUTION: Scaphosepalum tarantula is known from a few remaining forests near Las Tolas, not far from Quito, Ecuador, north-west of the city.

Habitat And ECology: The first plants of $S$. tarantula were seen growing in a cloud forest, not far from Las Tolas, about fifteen years ago and they still remain in the diminishing forests at the same location. It grows at an elevation of $\sim 1800 \mathrm{~m}$ a.s.l. as an ephiphyte and is sympatric with other orchids of subtribe Pleurothallidinae such as Scaphosepalum ophidion Luer, Dracula felix (Luer) Luer, Dracula dodsonii (Luer) Luer, Dracula marsupialis Luer \& Hirtz, Lepanthes kuijtiii Luer \& Hirtz and Platystele microscopica Luer. As with many other species in the genus, it grows in a very moist, low light environment, mainly directly in the trunk of big, remaining trees of the zone.

Conservation status: Even though a population of $S$. tarantula is still growing in the same area where it was first spotted about fifteen years ago, this area is being cut down and about $80 \%$ of the original forest is now gone. Urgent actions are required to preserve this remaining forest since not only to protect this new species, but also Dracula dodsonii, a very rare species. Most of the plants of $D$. dodsonii grow in an embankment with few epiphytic plants growing nearby. Not far from where $S$. tarantula grows, some protected forest such as Bellavista, Mindo Nambillo or even Pahuma are being protected, nevertheless, in about ten years of searching for a new locality of S. tarantula by the authors, we were unsuccessful at finding it elsewhere.

Scaphosepalum tarantula is unique among the species of Scaphosepalum because of a particular combination of characters. The leaves suffused with red-brown to dark purple stains at the petioles, the slender, shortly spiked- apex of the central sepal, the rhomboid petals and the pandurate lip with a shovel-shaped epichile distinguishes it from any other species in the genus (Fig. 1-4). This species has been mistaken as a color variation of $S$. fimbriatum mainly because of the long densely fimbriated-spiked tails of the lateral sepals (Fig. 3-4). Nevertheless, the different shape of the lip and petals distinguishes both species. The rhomboid versus subquadarate petals and the pandurate lip with the epichile shovelshaped versus the elliptical-subpandurate, trilobed lip, separates $S$. tarantula from $S$. fimbriatum. In $S$. tarantula some other features are different from any of the forms of S. fimbriatum including the slenderer penduncle and pedicels, the much slender, spiked apex of the dorsal sepal, and the tails of the lateral sepals more densely fimbriated and commonly projecting to the front instead of projecting to the sides of the flower which is seen frequently in $S$. fimbriatum (Figs. 1-4). Although S. zieglerae and $S$. beluosum also have fimbriated or speculated sepaline tails as well, the plants (to 35 and $25 \mathrm{~cm}$ respectively) and the flowers are larger than those of $S$. tarantula. Scaphosepalum beluosum have a pair of lobes near the middle of the lip that are not present in S. tarantula. The lip on S. ziegleriae has an obtuse epichile against the rhomboid epichile in $S$. tarantula. In S. zieglerae the flower bracts are conspicuous and larger than 

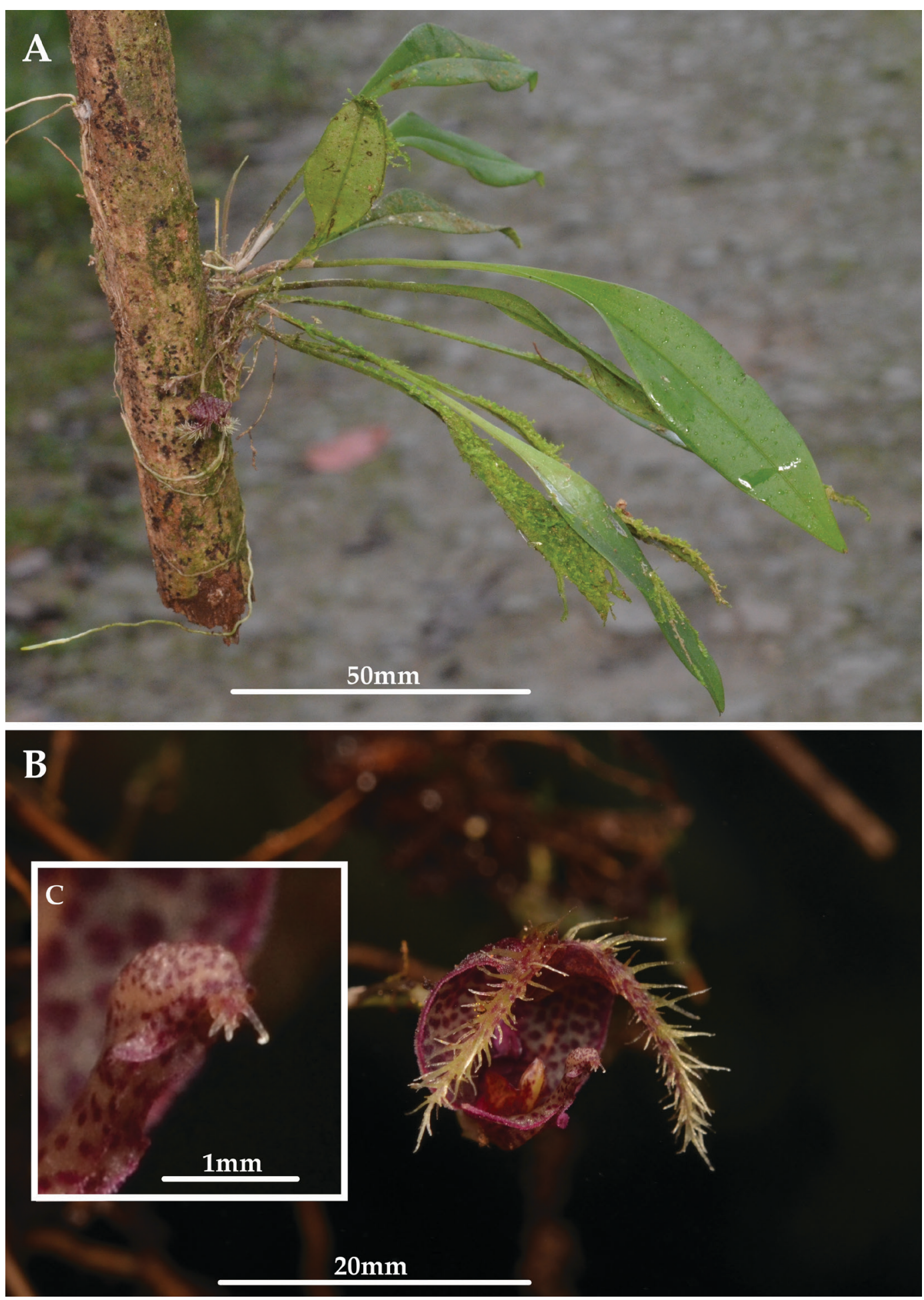

Figure 2. Scaphosepalum tarantula in situ. A. Plant and habit. B. Flower in situ. C. Close-up of the apiculate apex of the dorsal sepal. Photos by L. E. Baquero. 

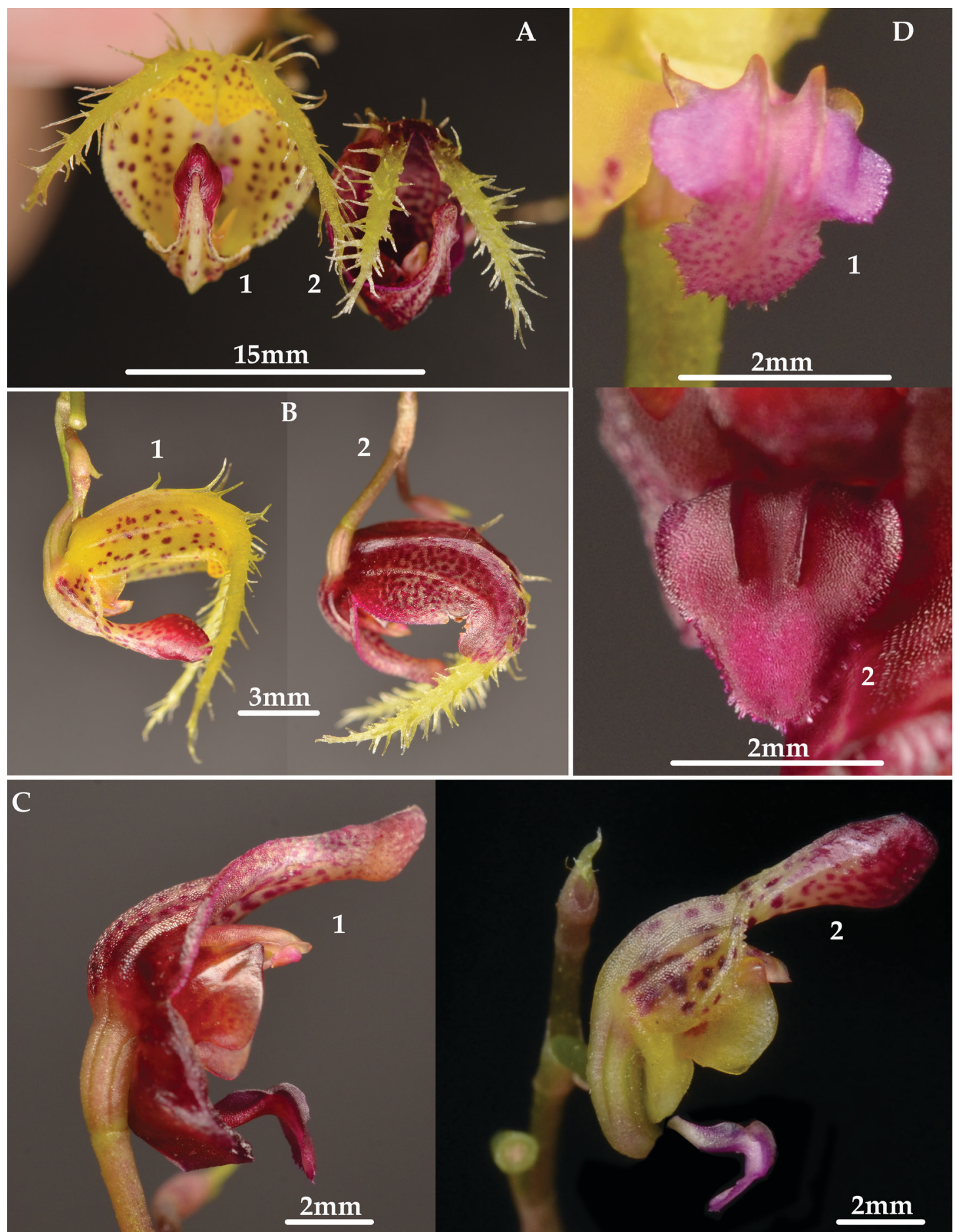

FIgURE 3. Comparison between Scaphosepalum tarantula and S. fimbriatum. A. Frontal view of the flowers: 1. S. fimbriatum, 2. S. tarantula. B. Lateral view of the flowers: 1. S. fimbriatum, 2. S. tarantula. C. Lateral view of dorsal sepals, column, petals and lip: 1. S. tarantula, 2. S. fimbriatum. D. Frontal view of the epichile of the lip: 1. S. fimbriatum, 2. S. tarantula. Photos by L. E. Baquero. 

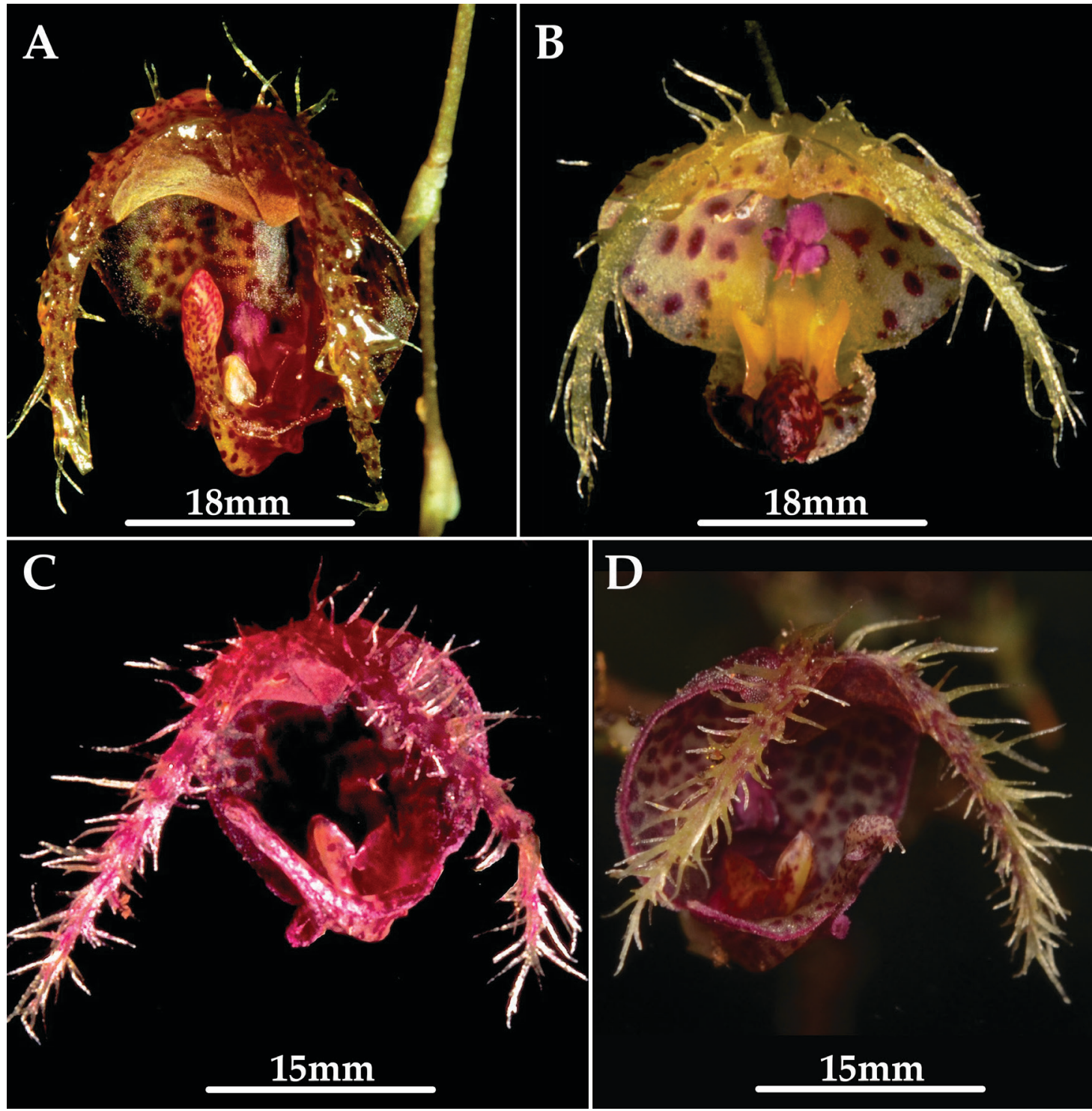

FIGURE 4. Comparion of the flowers of Scaphosepalum fimbriatum and S. tarantula. A. S. fimbriatum form from Esmeraldas province. B. S. fimbriatum form from Imbabura province. C-D. S. tarantula. Photos by A. Hirtz (A-C) and L. E. Baquero (D).

the pedicel, while in $S$. tarantula are shorter than the pedicel. Scaphosepalum fimbriatum was found growing in Imbabura and Esmeraldas provinces, north from where $S$. tarantula is found, in the province of Pichincha. The forms from Esmeraldas are darker in color than those from Imbabura, nevertheless, the color and shape of the lip, the petals, the dorsal tail and the rest of the morphology are the same in the two populations (Fig. 4).
AcKNOWLEDGEMENTS. The author acknowledges the Universidad de Las Americas (UDLA) for funding research on orchids in Ecuador. The Quito Botanical Garden is also acknowledged for cultivating $S$. tarantula and $S$. fimbriatum and making material available for the comparison of species. The Ministerio del Ambiente de Ecuador is acknowledged for issuing the Environmental Research Permit No. 008-2016-IC-FLO-DNB/MA. 


\section{LITERATURE CITED}

Baquero R., L. E. (2017). Scaphosepalum zieglerae, a showy new species in the genus (Pleurothallidinae: Orchidaceae). Lankesteriana, 17, 2, 305-310. doi: 10.15517/LANK.V17I2.30209

Chase, M. W., Cameron, K. M., Freudenstein J. V., Pridgeon, A. M., Salazar, G., van den Berg, C. \& Schuiteman, A. (2015). An updated classification of Orchidaceae. Botanical Journal of the Linnean Society, 177, 151-174.

Endara, L., Williams, N. \& Whitten, M. (2011). Filogenia molecular preliminar de Scaphosepalum (Orchidaceae: Pleurothallidinae). Lankesteriana, 11, 3, 245-252. doi: 10.15517/LANK.V11I3.18279

Karremans, A. P. (2016). Genera Pleurothallidinarum: an updated phylogenetic overview of Pleurothallidinae. Lankesteriana, 16, 219-241. doi: 10.15517/LANK.V16I2.26008

Karremans, A. P., Albertazzi, F. J., Bakker, F. T., Bogarin, D., Eurlings, M. C. M., Pridgeon, A., Pupulin, F. \& Gravendeel, B. (2016). Phylogenetic reassessment of Specklinia and its allied genera in the Pleurothallidinae (Orchidaceae). Phytotaxa, $272,001-036$.

Luer, C. A. (1988). Icones Pleurothallidinarum V: Systematics of Dresslerella and Scaphosepalum. Addenda to Porroglossum. Monographs in Systematic Botany from the Missouri Botanical Garden, 26, 21-106.

Luer, C. A. (1991). Icones Pleurothallidinarum VIII: Systematics of Lepanthopsis, Octomeria subgenus Pleurothallopsis, Restrepiella, Restrepiopsis, Salpistele and Teagueia. Addenda to Platystele, Porroglossum and Scaphosepalum. Monographs in Systematic Botany from the Missouri Botanical Garden, 39, 158, 161.

Luer, C. A. (1992). Icones Pleurothallidinarum IX: Systematics of Myoxanthus. Addenda to Platystele, Pleurothallis, subgenus Scopula and Scaphosepalum. Monographs in the Systematic Botany from the Missouri Botanical Garden, 44, 126-127.

Luer, C. A. (1993). Icones Pleurothallidinarum X: Systematics of Dracula (Orchidaceae). Monographs in Systematic Botany from the Missouri Botanical Garden, 46, 80-81.

Luer, C. A. (1998a). Icones Pleurothallidinarum XVI: Pleurothallis subgenera Crocodeilanthe, Rhynchopera, Talpinaria. Addenda to Dracula, Lepanthes of Ecuador, Masdevallia, Platystele, Pleurothallis, Restrepia and Scaphosepalum. Monographs in Systematic Botany from the Missouri Botanical Garden, 65, 119, 121-122.

Luer, C. A. (1998b). Icones Pleurothallidinarum XVII: Pleurothallis subgenus Pleurothallis sections Abortivae, Truncatae, Pleurothallis subsection Acroniae, Pleurothallis subgenera Dracontia and Unciferia. Addenda to Dracula, Lepanthes, Masdevallia, Porroglossum and Scaphosepalum. Monographs in Systematic Botany from the Missouri Botanical Garden, 72, 115-117, 120.

Luer, C. A. (2000). Icones Pleurothallidinarum XX: Jostia, Andinia, Barbosella, Barbrodria and Pleurothallis subgenera Antilla, Effusia and Restrepioidia. Addenda to Lepanthes, Masdevallia, Platystele, Pleurothallis, Restrepiopsis, Scaphosepalum and Teagueia. Monographs in Systematic Botany from the Missouri Botanical Garden, 79, 131, 139.

Luer, C. A. (2009). Miscellaneous new species in the Pleurothallidinae (Orchidaceae). Selbyana, 30(1), 19-20, 60-61.

Pridgeon, A. M., Solano, R. \& Chase, M. W. (2001). Phylogenetic relationships in Pleurothallidinae (Orchidaceae): combined evidence from nuclear and plastid DNA sequences. American Journal of Botany, 88, 12, 2286-2308.

Valenzuela Gamarra, L. (2015). A new species of Scaphosepalum Pfitzer (Pleurothallidinae: Orchidaceae), on the humid montane forest from Perú. Arnaldoa, 22, 339-346. 
